\title{
DEVELOPMENT OF BACTERIAL SENSITIVITY TEST BASED ON QUANTITATIVE DNA ASSESSMENT USING UV-VIS SPECTROSCOPY
}

\author{
[Cholid Badri, Budiman Bela, Anwar Ibrahim, Sutarmo Setiadji, Ajeng Pramastuty]
}

\begin{abstract}
This research's objective is to develop methods of testing the sensitivity of bacteria to various antibiotics using quantitative assessment of DNA during log phase with UV-Vis Spectroscopy. Methods used, samples of pathogenic E. coli bacteria after cultured in broth solution containing Ciprofloxacin for 7 hours were taken for DNA extraction technique. The isolated DNA was then quantitatively calculated based on light absorbance on UV-Vis spectrophotometer, where the values of absorbance density was converted into the concentration of DNA $/ \mathrm{ml}$. As a control arm of this study, the equal sample of pathogenic E. coli bacteria were cultured in broth solution without antibiotic. Results: The DNA concentration from 15 samples of E. coli in broth culture solution containing antibiotic solution was $7.3 \pm$ SD 2.28 ; whereas the DNA concentration in the control group was $10.3 \pm$ SD 2.51 which was significant different $(p .=0.000)$. This test was compared with conventional sensitivity test using disc diffusion method. It was demonstrated that the results were consistent with disc diffusion test that showing intermediate degree of sensitivity of the bacteria to the same antibiotic. These results indicate that administration of Ciprofloxacin in cultured pathogenic E. coli within the log phase of the bacteria inhibited the growth of DNA, which meant that the bacteria was sensitive to antibiotic. Conclusions: These results indicate that bacterial sensitivity test can be developed by DNA quantitative assessment during the growth of pathogenic bacteria using UV-Vis spectroscopy. This study will be followed by further sensitivity testing of various pathogenic bacteria to corresponding antibiotics for treatment of related disease.
\end{abstract}

Keywords - UV-Vis spectroscopy, optical density, DNA extraction, sensitivity test, pathogenic E. coli

\section{Introduction}

It has long been recognized that the growth and multiplication of bacteria can be divided into phases (1). The growth curve for a bacterial population is usually divided into four phases: lag phase, exponential or log phase, stationary phase and death phase. The exponential or log phase is the phase where all growing cells in the population are actively growing and dividing.

Quantitative measurement of bacterial suspension has been carried out by calculating all the parameters of the bacterial population i.e biomass, proteins, DNA, RNA, intracellular water and others (2). It has been obtained that differences in the absorbance of the phases of cell growth generates patterns of the overall cell quantity of each phase. It is known that the quantity of DNA is a dominant parameter in the calculation of the cell quantity in the phases of bacterial growth (3).
UV-Vis spectroscopy, which measures the amount of light that is attenuated by a solution or a suspension of particles, is a quantitative, reliable, and rapid analytical tool that can be immediately applied as a biosensor for the detection, identification, and enumeration of cells (4) UV-Vis spectroscopy of cells has been used to estimate the number of cells in a solution and their chemical composition, including nucleic acid and protein concentrations $(5,6,7)$. Based on the current study of UV-Vis spectroscopy, quantitative analysis appears to be a valid tool for assessment of bacterial virulence and for better microbiological characterization of E. coli bacteria for control and prevent health risks. The previous study demonstrated how UV-Vis spectroscopy measurements can yield information on DNA quantity in bacterial growth with a degree of detail and precision. It could reveal bacterial virulence by analyzing the pattern of DNA quantity during the growth phase (8). The pattern of DNA quantity during it's growth probably can be manipulated by some agents which affected DNA multiplication such as antibiotics, cytostatics and others. Some antibiotics can inhibit the growth of pathogenic bacteria which is affect the DNA of the bacteria with the end result will affect the DNA quantity in a specific time during the growth phase particularly in the log phase. The purpose of this study is how to measure the quantity of DNA that was inhibited by minimum concentration of antibiotics during their growth particularly in the log phase.

\section{Material and Methods}

\section{A. Bacterial culturing process}

Pathogenic E. coli cells were obtained from the Laboratory of Department of Microbiology, University of Indonesia, Jakarta. A bacterial suspension was prepared by culturing $0.1 \mathrm{~mL}$ of bacterial colony inoculated in $10 \mathrm{~mL}$ of nutrient broth for 24 hour. The nutrient broth was prepared by dissolving $5 \mathrm{~g}$ of peptone and $3 \mathrm{~g}$ of meat extract in $1000 \mathrm{~mL}$ of sterilized distilled water and then sterilizing the mixture in an autoclave. After 24 hours in fridge the bacteria was taken as much as 1 loop $(0,1 \mathrm{ml})$ then was put into $10 \mathrm{cc}$ broth solution. $1 \mathrm{cc}$ of the broth solution was put into $9 \mathrm{ml}$ of new broth solution containing Ciprofloxacin with concentration of $0,015 \mathrm{mg} / \mathrm{l}$. Ciprofloxacin solution was prepared by dilution of 3 tablets of 0,015 microgram per each tablet into distilled water up to $10 \mathrm{~mL}$. $1 \mathrm{ml}$ of the solution was put into $9 \mathrm{ml}$ broth solution containing E. coli bacteria. The bacteria in broth solution containing Ciprofloxacin was incubated for 7 
hours.. From the solutions that have been cultured for 7 hours, DNA extraction process will be performed.

\section{b. DNA extraction process}

Two $\mathrm{ml}$ solution that has been cultured for 7 hours were taken and centrifuged at $8000 \mathrm{rpm}$ for 10 minutes. The supernatant was discarded, the precipitate was added with 200 $\mu \mathrm{L}$ Phosphate Buffer Saline (PBS). Then $20 \mu \mathrm{L}$ Proteinase K was added and homogenized with vortex mixer for few seconds. $200 \mu \mathrm{L}$ Binding Buffer was added and homogenized with vortex mixer for few seconds. The solution was incubated at $60{ }^{\circ} \mathrm{C}$ for 10 minutes then $100 \mu \mathrm{L}$ of Isopropanol was added and homogenized with vortex mixer for few seconds. The liquid was transferred into the Binding Column with filter and then centrifuged at $8000 \mathrm{rpm}$ for 1 minute. The liquid was discarded, and the filter was removed to a new sample cup. $500 \mu \mathrm{L}$ Washing Buffer 1 (W1) was added and centrifuged at $8000 \mathrm{rpm}$ for 1 minute. The liquid was discarded and $500 \mu \mathrm{L}$ Washing Buffer 2(W2) was added (without replacing new sample cup) and was centrifuged at $8000 \mathrm{rpm}$ for 1 minute. The liquid was discarded and the precipitate was centrifuged at $12000 \mathrm{rpm}$ for 1 minute. The binding column was moved to a new sample cup and then added by $200 \mu \mathrm{L}$ of Elution Buffer / TE Buffer and centrifuged. $50 \mu \mathrm{L}$ of DNA solution was added into $450 \mu \mathrm{L}$ of TE Buffer in 1,5 ml sample column and homogenized.

\section{c. Calculation in the Spectrophotometer}

The liquid that was prepared beforehand was transferred to micro cell for measurement their normalized optical density (OD) with UV-Vis Spectrophotometer (Cary-5000, Agilent Technologies) at 240-320 nm wavelength. The same procedures were performed to the both groups.

\section{d. Disk Diffusion Test}

Disk diffusion test will be performed as the gold standard of bacterial sensitivity test and the results of the proposed sensitivity test in this study will be compared to it. The procedure is performed as follows : After minimum 24 hours in fridge, a loop of E. coli bacterial colony $(0,1 \mathrm{~mL})$ was taken and diluted in $3 \mathrm{ml} \mathrm{NaCl} 0.9 \%$ solution and then was compared to McFarland standard solution to determine the level of turbidity of bacterial solution. The standard of 0.50 $0.55 \mathrm{McFarland}$ was used which was equivalent with solution containing between $10^{7}$ and $10^{8} \mathrm{cfu} / \mathrm{ml}$. The solution was poured evenly at the surface of agar in Petri dish. Two tablets of 0.015 microgram Ciprofloxacin were put on the surface of the agar than incubated for 24 hours. The reading of the results obtained from the formation of inhibition zones on agar and width of the zone will be compared to the standard width of inhibition zone according to the existing standard with a resistant category, intermediate and sensitive.

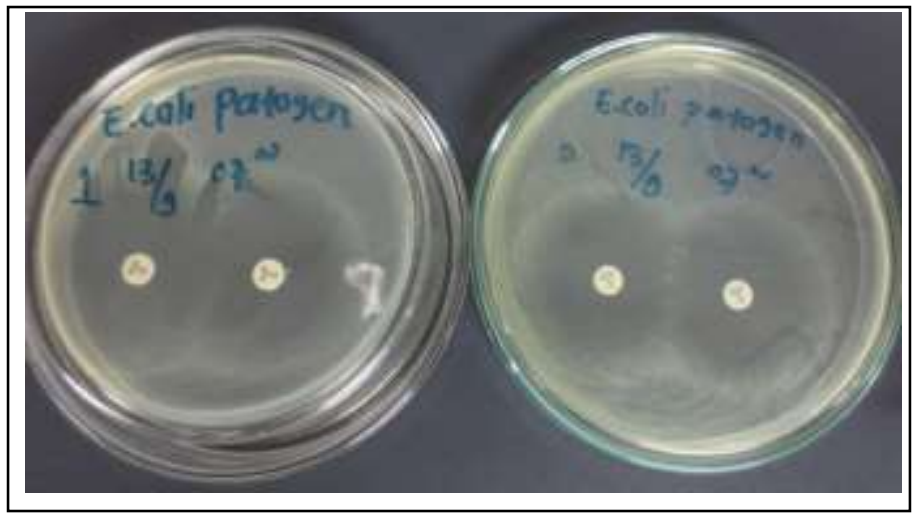

Figure 1. Disk diffusion test

\section{Results}

Study has been conducted in two groups of study consisted of 15 samples in each group . The first group consisting samples of pathogenic E. coli bacteria that were cultured in broth solution containing Ciprofloxacin, while the second group was a group of bacteria cultured in solution without Ciprofloxacin.

Two experimental groups will be compared in the amount of the DNA contents after 7 hour cultivation. At every examination a graph was obtained showing the levels of DNA concentration absorbance at wavelengths between 240-320 $\mathrm{nm}$. As a correction to the purity of the examined DNA, it was taken into account the concentration of DNA at a wavelength of $280 \mathrm{~nm}$.

A typical presentation of measurement of one sample of cultured pathogenic E. coli with Ciprofloxacin measured using UV-VIS Spectroscopy with visible chart of DNA concentration absorbance at a wavelength of $240-320 \mathrm{~nm}$ was demonstrated in figure 2 .

On this figure the $\mathrm{Y}$ axis represents DNA absorbance (optical density) in the range of $-0,05$ to 0,05 and the $\mathrm{X}$ axis represents the wavelength from $240-320 \mathrm{~nm}$.

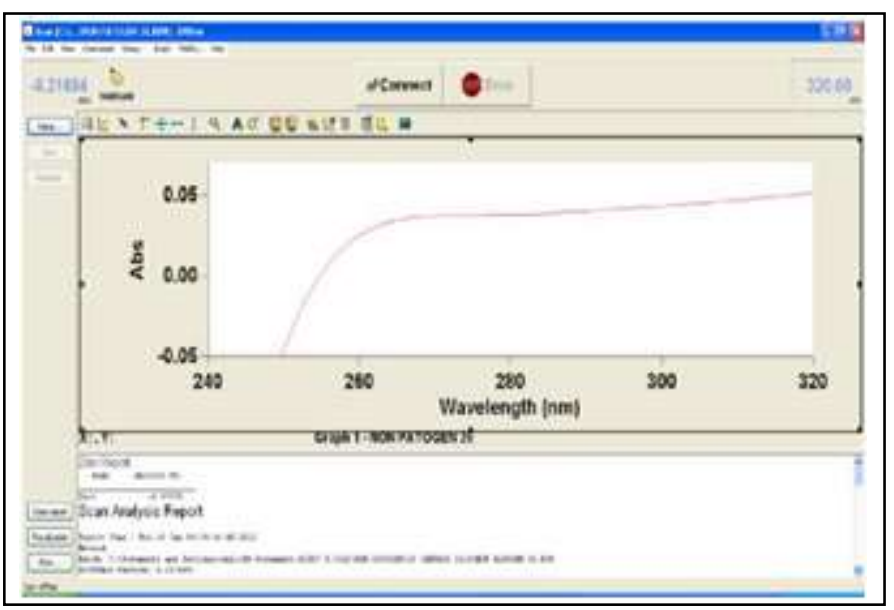

Figure 2. Graphs absorbance of DNA quantity on a wavelength of $240 \mathrm{~nm}$ to $320 \mathrm{~nm}$ at 7 hours incubation of pathogenic bacteria with Ciprofloxacin. 
Numerical data of DNA absorbance of pathogenic E coli with Ciprofloxacin at 7 hour incubation can be seen in Table 1. In this table the Optical Densities were seen at 260, 280 and 320 $\mathrm{nm}$ wavelengths with corresponding DNA concentration and purity.

Table 1. Optical densities at 260, 280 and $320 \mathrm{~nm}$ wavelengths with corresponding DNA concentration and purity of pathogenic bacteria and Ciprofloxacin after 7 hour incubation.

\begin{tabular}{cccccc}
\hline No & A/260 & A/280 & A/320 & \multicolumn{2}{c}{ Spectrophotometer } \\
& & & & Concentration & Purity \\
\hline 1 & 0.019 & 0.032 & 0.043 & 9.5 & 2.18 \\
2 & 0.008 & 0.024 & 0.040 & 4.0 & 2.00 \\
3 & 0.011 & 0.026 & 0.042 & 5.5 & 1.94 \\
4 & 0.011 & 0.026 & 0.041 & 5.5 & 2.00 \\
5 & 0.010 & 0.026 & 0.041 & 5.0 & 2.07 \\
6 & 0.008 & 0.024 & 0.040 & 4.0 & 2.00 \\
7 & 0.009 & 0.027 & 0.041 & 4.5 & 2.29 \\
8 & 0.015 & 0.029 & 0.042 & 7.5 & 2.08 \\
9 & 0.007 & 0.024 & 0.041 & 3.5 & 2.00 \\
10 & 0.010 & 0.026 & 0.042 & 5.0 & 2.00 \\
11 & 0.013 & 0.028 & 0.043 & 6.5 & 2.00 \\
12 & 0.010 & 0.026 & 0.041 & 5.0 & 2.07 \\
13 & 0.013 & 0.028 & 0.043 & 6.5 & 2.00 \\
14 & 0.013 & 0.029 & 0.044 & 6.5 & 2.07 \\
15 & 0.012 & 0.028 & 0.043 & 6.0 & 2.07 \\
\hline
\end{tabular}

To evaluate the purity of DNA, computation was performed for the ratio between the absorbance at $260 \mathrm{~nm}$ divided by the absorbance at $280 \mathrm{~nm}$. Good quality DNA is $\mathrm{A} 260 / \mathrm{A} 280=1.7$ to 2.0 . The ratio of less than 1.7 could not be used for precise calculation because it shows sufficient DNA contamination.

Corresponding figure of one sample of pathogenic E. coli in UV-Vis Spectrophotometer of DNA concentration absorbance at a wavelength of $240-320 \mathrm{~nm}$ at 7 hour after incubation of E. coli without Ciprofloxacin was presented on Figure 3

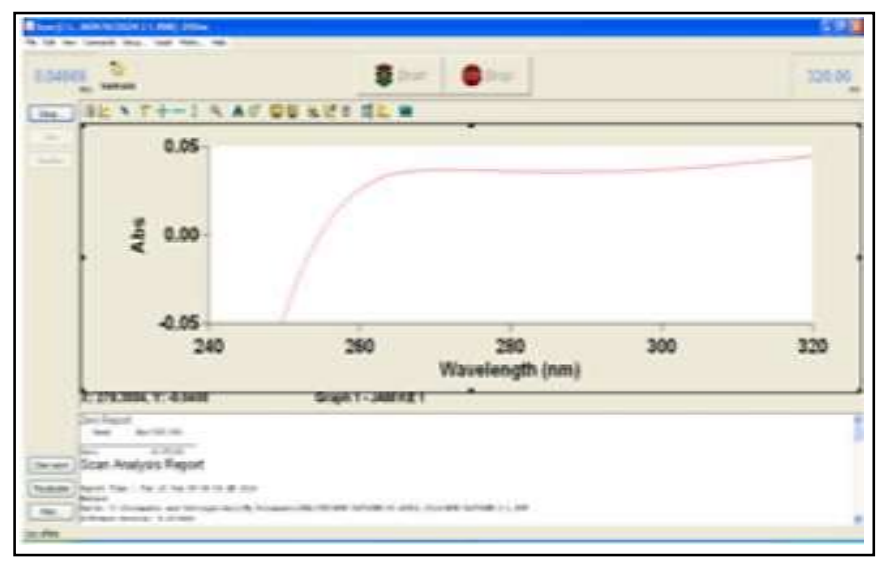

Figure 3. Graphs absorbance of DNA quantity on a wavelength of 240 to 320 $\mathrm{nm}$ at 7 hours incubation of bacteria without Ciprofloxacin.
Corresponding numerical data of DNA absorbance of pathogenic E. coli at 7 hour incubation of E. coli bacteria without Ciprofloxacin were shown on table 2 .

Table 2. Optical densities at 260, 280 and $320 \mathrm{~nm}$ wavelengths with corresponding DNA concentration and purity of pathogenic bacteria without Ciprofloxacin after 7 hour incubation.

\begin{tabular}{cccccc}
\hline & & & & \multicolumn{2}{c}{ Spectrophotometer } \\
No. & $\mathrm{A} / 260$ & $\mathrm{~A} / 280$ & $\mathrm{~A} / 320$ & Concentration & Purity \\
\hline 1 & 0.034 & 0.041 & 0.049 & 17.0 & 1.88 \\
2 & 0.039 & 0.044 & 0.049 & 19.5 & 2.00 \\
3 & 0.032 & 0.040 & 0.048 & 16.0 & 2.00 \\
4 & 0.033 & 0.040 & 0.047 & 16.5 & 2.00 \\
5 & 0.031 & 0.04 & 0.049 & 15.5 & 2.00 \\
6 & 0.018 & 0.030 & 0.043 & 9.0 & 1.92 \\
7 & 0.019 & 0.031 & 0.042 & 9.5 & 2.09 \\
8 & 0.024 & 0.034 & 0.042 & 12.0 & 2.25 \\
9 & 0.025 & 0.034 & 0.043 & 12.5 & 2.00 \\
10 & 0.023 & 0.033 & 0.044 & 11.5 & 1.91 \\
11 & 0.026 & 0.035 & 0.046 & 13.0 & 1.82 \\
12 & 0.030 & 0.040 & 0.049 & 15.0 & 2.11 \\
13 & 0.018 & 0.03 & 0.042 & 9.0 & 2.00 \\
14 & 0.017 & 0.029 & 0.041 & 8.5 & 2.00 \\
15 & 0.017 & 0.030 & 0.042 & 8.5 & 2.08 \\
\hline
\end{tabular}

The concentration of DNA from 15 samples of E. coli pathogen in culture broth containing antibiotic solution was $7.3 \pm$ SD 2.28; whereas in the control group the DNA concentration was $10.3 \pm \mathrm{SD} 2.51$. It was shown that there was a significant difference $(p=0.002$ between groups which means that the DNA quantity of pathogenic E. coli with Ciprofloxacin were lower than in pathogenic E. coli without the antibiotic.

There results were consistent with the results of Disc diffusion test as seen in the Table 3. The disc diffusion tests were performed in two separate days with 2 and 3 dishes for each day. Two Ciprofloxacin tablets were put in 1 Petri dish for a total 5 dishes resulting of 10 areas of inhibition zones. The inhibition zones were measured in the range of $22-26$ $\mathrm{mm}$ which were in sensitive category. These results strongly indicated that administration of Ciprofloxacin in incubated pathogenic E. coli in the log phase inhibited the growth of DNA during it's log phase, which meant that the bacteria was sensitive to the corresponding antibiotic. 
Proc. of The Third Intl. Conf. On Advances in Applied Science and Environmental Technology - ASET 2015

Copyright (C) Institute of Research Engineers and Doctors, USA .All rights reserved.

ISBN: 978-1-63248-084-2 doi: 10.15224/ 978-1-63248-084-2-34

\begin{tabular}{|c|c|c|c|}
\hline \multirow{2}{*}{ No. } & Resistant & Sensitive & Intermediate \\
\hline & $<14 \mathrm{~mm}$ & $>22 \mathrm{~mm}$ & $15-21 \mathrm{~mm}$ \\
\hline 1 & & $25 \mathrm{~mm}$ & \\
\hline 2 & & $23 \mathrm{~mm}$ & \\
\hline 3 & & $23 \mathrm{~mm}$ & \\
\hline 4 & & $26 \mathrm{~mm}$ & \\
\hline 5 & & $23 \mathrm{~mm}$ & \\
\hline 6 & & $22 \mathrm{~mm}$ & \\
\hline 7 & & $23 \mathrm{~mm}$ & \\
\hline 8 & & $25 \mathrm{~mm}$ & \\
\hline 9 & & $25 \mathrm{~mm}$ & \\
\hline 10 & & $26 \mathrm{~mm}$ & \\
\hline
\end{tabular}

Diffusion Test

\section{Discussion}

The sensitivity of bacteria against antibiotics can be tested with several method i.e disc diffusion test and MIC test. Both tests concerning of antibiotic to inhibit the bacterial growth within specific time usually within 24 hours. Minimum Inhibitory Concentrations (MICs) are defined as the lowest concentration of an antimicrobial that will suppressed the visible growth of a microorganism after overnight incubation, and minimum bactericidal concentrations (MBCs) as the lowest concentration of antimicrobial that will prevent the growth of an organism after subculture on to antibiotic-free media. MICs are used by diagnostic laboratories mainly to confirm resistance, but most often as a research tool to determine the in vitro activity of new antimicrobials, and data from such studies have been used to determine MIC breakpoints. MBC determinations are undertaken less frequently and their major use has been reserved for isolates from the blood of patient. MIC test that needs 24 hour incubation, the test can be conducted only 7 hour incubation. It can save time in the both MIC and disc diffusion test that must be waited after 24 hours incubation. From the results obtained it is possible to test bacterial sensitivity against various antibiotics that were allegedly sensitive or resistant simultaneously. Therefore it can also be used to test the sensitivity of various other bacteria with associated antibiotics.

\section{v. Conclusion}

These results indicate that bacterial sensitivity test can be developed by DNA quantitative assessment during the log phase of pathogenic bacteria using UV-Vis spectroscopy. The proposed sensitivity test could be more efficient and would be faster than conventional sensitivity test. This study will be followed by further sensitivity testing of various antibiotics to corresponding pathogenic bacteria for treatment of related disease.

\section{A. Authors and Affiliations}

These are authors and affiliations that contribute in this research.

\section{Cholid Badri 1, Budiman Bella 2, V. Sutarmo Setiadji 1, Anwar Ibrahim 1, Ajeng Pramastuty 1.}

\section{Center for the Study and Development of Biomedical Engineering, Graduate Program, University of Indonesia.}

\section{Faculty of Medicine, University of Indonesia.}

\section{References}

[1] Wade, H. E. (1952). Observations on the Growth Phases of Escherichia coli, American Type ' B 'J. gen. Microbiol. 7, 18-23

[2] Cooper. S. (1995). Bacterial Growth and Division. In Meyers, R. A. (ed.). Molecular Biology and Biotechnology: A Comprehensive Desk Reference, Wiley Publisher, 6-7, Michigan.

[3] Steen H. B., Boye E., (1980), Bacterial Growth Studied by Flow Cytometry. Cytometry (Vol. 1 No. 1), 32-36

[4] Park C.W, YooK.Y, Byeon Y.H, Kim K, Hwang J. (2012) Development of Rapid Assessment Method to Determine Bacterial Viability Based on Ultraviolet and Visible (UV-Vis) Spectroscopy Analysis Including Application to Bioaerosols. Aerosol and Air Quality Research, 12: 399-408

[5] Catalina E, Alupoaei Luis H, García-Rubio (2003). Growth Behavior of Microorganisms Using UV-Vis spectroscopy: Escherichia coli Manuscript 03-336. R1 in Biotechnology \& Bioengineering

[6] Alupoaei, C. E., J. A. Olivares, and García-Rubio, L. H (2002) Quantitative Analysis of Prokaryotic Cells: Vegetative Cells and Spores, Report No: LA-UR026586, Los Alamos National Laboratory, Los Alamos, MN

[7] Badri C, Bella B, Ibrahim AS, Setiadji S. Assessment Method for Bacterial Virulence Based on Ultraviolet and Visible (UV-Vis) Spectroscopy Analysis. $7^{\text {th }}$ WACBE World Congress on Bioengineering, Singapore 6-8 July, 2015. IFMBE Proceedings Vol. 52. 2015.

[8] Andrews JM. Determination of minimum inhibitory concentrations. J. Antimicrob. Chemother. (2001)48 (suppl 1): 5-16.

[9] Alupoaei, C. E., García-Rubio, L. H., Heler, L., Davis, C. A., Cannons, P., Amuso, and Cattani, J. (2003) Novel Method for the Discrimination of Microorganisms using Spectroscopy, Paper No 1998, American Society for Microbiology, Washington, DC.

[10] Callahan, M. C., J. B. Rose and García-Rubio, L. H (2003) The Use of Multiwavelength Transmission Spectroscopy for the Characterization of Cryptosporidium parvum Oocysts: - Quantitative Interpretation. Environmental Science \& Technology, 37, 5254-5261,

[11] Feng P, Weagant S, Grant, M . 2002, Enumeration of Escherichia coli and the Coliform Bacteria. Bacteriological Analytical Manual (8th ed.). FDA/Center for Food Safety \& Applied Nutrition, Boston.

[12] Fotadar U, Zaveloff P, Terracio L. 2005, Growth of Escherichia coli at elevated temperatures. J. Basic Microbiol.45(5):403-4.

[13] Jan Hudzicki (20013). Kirby-Bauer Disk Diffusion Susceptibility Test Protocol. ASM Microbel Library, American Society for Microbiology.

About Author (s):

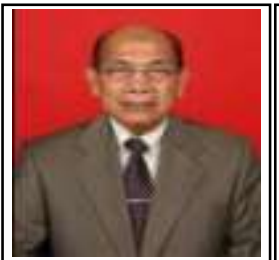

[Prof. Cholid Badri MD, $\mathrm{PhD}$, is the Head of Biomedical Engineering Graduate Program, University of Indonesia. His focus research mostly on medical sciences. At present he listed as lecturer at Graduate Program since 2006 and focused on Biomedical Engineering study] ... 